AL MURABBI: Jurnal Pendidikan Agama Islam

P-ISSN (cetak) : 2477- 8338

E-ISSN (online) : 2548- 1371
Program Studi Pendidikan Agama Islam

https://jurnal.yudharta.ac.id/v2/index.php/pai

Volume 6 Nomor 1 Desember 2020

\title{
MULTICULTURAL-BASED CURRICULUM CONCEPTION
}

\author{
${ }^{1}$ Asmuki, ${ }^{2}$ Achmad Yusuf, ${ }^{3}$ Abdul Aziz, ${ }^{4}$ Salim \\ 1,3University Ibrahimy of Situbondo, East Java, Indonesia \\ 2University Yudharta of Pasuruan, East Java, Indonesia \\ ${ }^{4}$ University Raden Rahmat Islamic of Malang, East Java, Indonesia \\ 1asmuki@ibrabimy.ac.id,2achys@@yudharta.ac.id,33aziznoer57@gmail.com,salim@gmail.com

\begin{abstract}
This study aims to describe about 1) Classification of multicultural-based curriculum in various points of view, (2) Principles and Principles of multicultural-

Received: based education curriculum preparation. This research is designed in the form of

Accepted: Factual Curriculum, and (c) Hidden Curriculum. Second: The Structure and Broad Fields Curriculum (c) and. (4) Integrated Curriculum. Third: The Scope of Use perspective is classified into 3 i.e. (a) national curriculum, (b) state curriculum, (c) and school curriculum.

(2) Principles in designing a multicultural-based curriculum namely (a) The Principle of Child Psychology, (b) the Principle of National Sociology, (c) the Principle of Development of $W$ orld Science and Technology, and (d) the Principle of Pancasila as the Philosophy of the Nation. While the Principles of Curriculum Preparation in Multicultural Education include: (a) relevance principle, (b) flexibility, (c) continuity, (d) efficient, and (e) effective.
\end{abstract} \\ October $18^{\text {th }} 2020$ library research. The results of this study concluded that (1) classification of \\ Revised: Multicultural Based Curriculum from three points of view, namely First: Concept \\ November $18^{\text {th }} 2020$ and Implementation Perspective is classified into 3 namely (a) Ideal Curriculum (b) \\ December $22^{\text {th }} 2020$ Subject Matter Perspective is classified into 4 i.e. (a) Sparated Curriculum. (b) \\ Keywords: $\mid$ Multicultural Based, curriculum.
}

\section{PENDAHULUAN}

Kajian multikulturalisme dalam pendidikan semakin ramai dibicarakan. Tulisan dan gagasan tentang pendidikan multikultural pun kian bertambah dari waktu ke waktu. Gagasan-gagasan tersebut mengungkapkan banyak hal sejak konseptual pendidikan multikultural hingga praktis pendidikan multikultural, baik yang berkembang di berbagai negara seluruh dunia atau pun di negara Indonesia. di Indonesia sendiri litertur-literatur pendidikan multikultural memang masih terbatas, namun terus berkembang dari waktu ke waktu, baik di lingkungan pendidikan pesantren seperti disertasi yang ditulis oleh Abdullah Aly yang sudah dibukukan dengan judul "Pendidikan Islam Multikultural di Pesantren,"1 atau di lingkungan pendidikan di luar pesantren misalnya buku dengan judul "Mengelola Keragaman di Sekolah; Gagasan dan Pengalaman Guru,"2 dan buku-buku lain yang berserakan di rak-rak buku.

Keragaman budaya Nusantara dari aspek ras, suku, bangsa, bahasa, adat-istiadat, kesenian, agama, pemahaman keagamaan, moral, dan sebagainya yang tersebar di seluruh bumi Nusantara

\footnotetext{
1 Abdullah Aly, Pendidikan Islam Multikultural di Pesantren: Telaah terhadap Kurikulum Pondok Pesantren Modern Islam Assalam Surakarta, Yogyakarta, Pustaka Belajar, 2011.

2 Anis Farikhatin et.al., Mengelola Keragaman di Sekolab: Gagasan dan Pengalaman Guru, Yogyakarta, CRCS Sekolah Pascasarjana UGM, 2016.
} 
menunjukkan kekayaan yang luar biasa bagi negara ini di satu sisi, dan menjadi ancama disintegrasi bangsa di sisi lain. Keragaman ini menuntut dunia pendidikan berbenah diri dengan melakukan penyesuaian diri tanpa harus melalaikan nilai-nilai khas yang ada di dalamnya. Desain kurikulum pendidikan multikultural merupakan salah satu pilihan -bukan satu-satunya pilihan - menghadapi keragaman budaya dan semakin derasnya gerakan radikalisme.

Desain kurikulum pendidikan multicultural dapat dilakukan dengan memulai perumusan tujuan pendidikan yang dilanjutkan dengan pengejawantahan nilai-nilai multikultural dalam bahan ajar dan model pembelajaran yang bernuansa multikultur dengan memodifikasi kurikulum dari berbagai sudut pandangnya sebagaimana ditungkan pada pembahasan-pembahasan sebelumnya. Dalam penyusunan kurikulum berbasis multikultural juga harus diperhatikan asas-asas dan prinsip penyusunan kurikulum agar kurikulum multikultural yang konsep tidak berseberangan dengan nilainilai kultur yang ada di sekitar sekolah secara khusus dan kultur negara secara umum.

Kajian artikel ini akan mengkaji tentang kurikulum berbasis multikultural yang fokus pembahasannya (1) Klasifikasi kurikulum berbasis multikultural dalam berbagai berbagai sudut pandang, (2) Asas dan Prinsip penyusunan kurikulum pendidikan berbasis multikultural.

\section{METODE}

Penelitian ini didesain dalam bentuk penelitian kepustakaan (library research) dengan merujuk beberapa sumber kepustakaan yang berkaitan dengan kurikulum yang meliputi klasifikasi, asas dan prinsip penyusunan kurikulum berbasis multicultural. penelitian ini bersumber dari beberapa buku referensi yang berkaitan dengan kurikulum. Penelitian ini mengkaji dan menganalisis dengan menggunakan pendekatan isi kurikulum serta yang berkaitan dengan pengklasifikasian, asas, prinsip dalam penyusunan kurikulum berbasis multikultural.

\section{HASIL DAN PEMBAHASAN}

\section{Hakikat Kurikulum Berbasis Multikultural}

Secara umum, kurikulum dapat dipahami secara sempit dan luas. Kata kurikulum berasal dari bahasa Latin, yaitu currere yang arti harfiahnya adalah lapangan perlombaan lari. Lapangan tersebut ada batas start dan batas finish. Maka, tidak heran bila kurikulum kerap diartikan sempit yaitu sebagai subject matter atau materi pelajaran yang garis start-nya sudah ditentukan, begitu pula batas finish-nya telah ditetapkan. ${ }^{3}$ Berdasarkan sejarah munculnya, istilah kurikulum pertama kali dikenal dalam dunia olahraga. Seiring perkembangan ilmu pengetahuan, penggunaan dan pemaknaan kurikulum juga bergeser. Sebagaimana dikutip Nik Nurhayati, pada tahun 1955, istilah kurikulum sudah digunakan dalam dunia pendidikan. Namun, pergeseran penggunaan istilah

3 Dakir, Perncanaan Dan Pengembangan Kurikulum, Jakarta, Rineka Cipta, 2004, h. 2. 
AL MURABBI: Jurnal Pendidikan Agama Islam https://jurnal.yudharta.ac.id/v2/index.php/pai

Volume 6 Nomor 1 Desember 2020

kurikulum dari dunia olahraga ke dunia pendidikan belum menunjukkan adanya perubahan definisi kurikulum. Dalam kesempatan ini, kurikulum masih diartikan sebagai sejumlah matapelajaran di sekolah atau mata kuliah di perguruan tinggi yang harus ditempuh untuk mencapai suatu tingkat tertentu atau ijazah. ${ }^{4}$

Selanjutnya, definisi kurikulum mengalami perkembangan dari sekedar subject matter ke beberapa aspek lain secara bertahap dan beraneka ragam. Misalnya definisi yang dikutip Ali Mudlofir dari beberapa pakar, di antaranya ada yang menyebut kurikukum sebagai seluruh pengalaman murid di bawah bimbingan sekolah, ada pula yang men-generalisir tidak hanya di bawah bimbingan sekolah tetapi dalam tempaan hidup secara umum, ada juga yang mendefinisikannya semua pembelajaran yang direncanakan, dan seterusnya. ${ }^{5}$

Dari beberapa statemen makna kurikulum di atas dapat dipahami bahwa kurikulum tidak lagi dipahami sebagai konten, tetapi sudah meluas pada pengalaman murid sendiri apakah itu diperoleh melalui konten yang ditetapkan sekolah atau tidak. Yang paling penting di sini adalah pengalaman tersebut di bawah bimbingan sekolah. Definisi kurikulum yang menyatakan bahwa pengalaman murid yang diperoleh berdasarkan tempaan hidup lebih tepat untuk pengertian kurikulum yang bukan hanya dalam lingkup sekolah, tetapi kurikulum dalam dunia pendidikan secara umum seperti pendidikan melalui pelatihan-pelatihan, kursus, bimbingan, dan sebagainya.

Berdasarkan perkembangan konsepsi kurikulum di atas, Dakir mendefinisikan kurikulum sebagai suatu program pendidikan yang berisikan berbagai bahan ajar dan pengalaman belajar yang diprogramkan, direncanakan, dan dirancangkan secara sistemik atas dasar norma-norma yang berlaku yang dijadikan pedoman dalam proses pembelajaran bagi tenaga kependidikan dan peserta didik untuk mencapai tujuan pendidikan. ${ }^{6}$ Dalam Undang-undang Nomor 20 Tahun 2003 tentang Sistem Pendidikan Nasional disebutkan, "kurikulum adalah seperangkat rencana dan pengaturan mengenai tujuan, isi, dan bahan pelajaran serta cara yang digunakan sebagai pedoman penyelenggaraan kegiatan pembelajaran untuk mencapai tujuan pendidikan tertentu."’7

Menurut PMA tentang Kurikulum 2013, definisi kurikulum yang ditampilkan dalam UU Sisdiknas di atas mengandung dua dimensi kurikulum, yaitu: (1) rencana dan pengaturan mengenai tujuan, isi, dan bahan pelajaran; dan (2) cara yang digunakan dalam kegiatan pembelajaran. ${ }^{8}$ Klasifikasi dimensi kurikulum menjadi dua yang dimuat dalam PMA tersebut terlalu singkat. Ada satu dimensi yang terlupakan dalam definisi kurikulum yang ada di UU Sisdiknas, yaitu statemen "

\footnotetext{
${ }^{4}$ Nik Nurhayati, Pengembangan Kurikulum Pendidikan Agama Islam, Bandung, Alfabeta, 2011, h. 1-2.

5 Ali Mudlofir, Aplikasi Pengembangan Kurikulum Tingkat Satuan Pendidikan dan Bahan Ajar dalam Pendidikan Agama Islam, Jakarta, Rajagrafindo Persada, 2011, h. 2.

6 Dakir, Perncanaan, hlm. 3.

${ }^{7}$ Undang-undang Nomor 20 Tahun 2003 tentang Sistem Pendidikan Nasional BAB I, Pasal 1 Nomor (19).

${ }^{8}$ Peraturan Menteri Agama Nomor 912 Tahun 2013 tentang Kurikulum Madrasah 2013 Matapelajaran Pendidikan Agama Islam dan Bahasa Arab BAB I Nomor 2 Sub a Pengertian Kurikulum.
} 
untuk mencapai tujuan pendidikan tertentu." Hemat penulis, pernyataan ini mengandung makna evaluasi yang harus dilakukan dalam pendidikan. Sebab, tercapai atau belum tujuan pendidikan tertentu dapat diketahui dengan evaluasi. Maka dari itu, berdasarkan definisi kurikulum pada UU Sisdiknas, dimensi kurikulum bukan dua, melainkan tiga, yaitu: dimensi rencana atau pengaturan, dimensi cara pembelajaran, dan dimensi evaluasi.

Masing-masing dimensi dapat dikembangkan lagi. Pada tataran dimensi rencana dan pengaturan dapat dipahami dengan perumusan tujuan pendidikan yang hendak dicapai. Setelah tujuan pendidikan ditetapkan, langkah selanjutnya adalah perencanaan dan penetapan komponen matapelajaran yang sejalan dengan tujuan yang telah ditetapkan. Idealnya, setelah nama-nama matapelajaran ditetapkan adalah langkah pengorganisasian materi-materi menjadi bahan ajar yang sesuai dengan karakter sekolah dan tujuan yang ditetapkan. Bila tahap perencanaan dan pengaturan tujuan, isi, dan bahan pelajaran ini dikaitkan dengan multikulturalisme, maka tujuan yang dibuat misalnya terwujudnya peserta didik yang intelek dan religius-humanis, maka untuk mencapai tujuan mulia ini perlu dibuat struktur matapelajaran yang terpadu antara aspek intelektual dan religiushumanis. Implementasinya dalam struktur matapelajaran adalah mengadopsi struktur matapelajaran yang telah dibuat pemerintah sesuai standar isi, kemudian ditambah dengan muatan lokal yang mengarah pada pembentukan sikap religius humanis. Terakhir yang harus dilakukan adalah membuatkan bahan ajar masing-masing matapelajaran yang telah ditetapkan dengan mengintensifikasi nilai-nilai religius-humanis pada bahan ajar yang dibuat.

Pada tataran cara pembelajaran sebenarnya ada elemen lain yang terlibat yaitu murid, siswa, dan cara itu sendiri. Sedangkan cara masih dapat dikembangkan menjadi pendekatan pembelajaran, model pembelajaran, metode pembelajaran, dan strategi pembelejaran. Untuk melahirkan lulusan yang intelek dan religius-humanis maka diperlukan guru yang kompeten di bidangnya dan berkarakter religius-humanis. Begitu pula dalam tataran pembelajaran, guru harus menganut pendekatan pembelajaran yang berpusat pada keaktifan siswa (student centered) yang terejawantahkan pada model, metode, dan strategi yang digunakan yang menunjukkan proses-proses religiushumanis. Selanjutnya adalah tahap evaluasi yang harus dilakukan secara menyeluruh.

\section{Klasifikasi Kurikulum Berbasis Multikultural}

Setidaknya ada tiga sudut pandang untuk membagi kurikulum ke dalam beberapa kelas, yaitu kurikulum dipandang dari segi konsep dan pelaksanaannya, dari segi struktur dan materi pelajarannya, dan dari segi proses penyusunannya. 


\section{a. Pespektif Konsep dan Pelaksanaan}

Kurikulum dipandang dari perspektif konsep dan pelaksanaannya diklasifikasikan ke dalam tiga kelompok, yaitu:?

1) Kurikulum Ideal

Yang dimaksud Kurikulum Ideal yaitu dokumen-dokumen ideal tentang pelaksanaan pembelajaran yang dicita-citakan yang seharusnya dicapai, ${ }^{10}$ misalnya tujuan "yang hendak dicapai" adalah lahirnya generasi muslim intelek yang religius-humanis, yang didukung dengan dokumen pengorganisasian isi dan bahan ajar "yang harus" memuat nilainilai religius-humanis pada setiap bab, bahkan Kompetensi Dasar, tiap-tiap matapelajaran, dan dilengkapi dengan guru-guru yang berjiwa dan berperilaku religius-humanis, dan seterusnya.

2) Kurikulum Faktual

Maksud dari Kurikulum Faktual ialah dokumen-dokumen dari seluruh kegiatan pembelajaran yang riil diterapkan oleh guru-murid di bawah supervisi kepala sekolah. Seringkali antara Kurikulum Faktual berbeda dengan Kurikulum Ideal, namun perbedaan tersebut seharusnya terus diupayakan tidak terlalu jauh. ${ }^{11}$

Contoh perbedaan kurikulum ideal dengan implementasinya yang riil adalah sebagaimana telah di sebutkan di atas, misalnya, diinginkan muatan religius-humanis "yang harus" terintegrasi pada setiap bab, bahkan KD tiap matapelajaran, namun sangat mungkin hal itu tidak terealisir sama sekali atau hanya terealisir pada matapelajaran tertentu dan babbab tertentu pula misalnya pada matapelajaran PAI dan PKn. Perbedaan tidak hanya terjadi pada kurikulum faktual dari yang ideal, tetapi juga seringkali terjadi perbedaan praktik RPP dengan implementasinya pada saat guru menerapkannya di dalam kelas; seringkali yang terencana dengan rapi tidak terlaksana dan sebaliknya yang tidak terencana terlaksana secara spontan. Yang kedua ini yang biasanya diistilahkan dengan Hidden Curriculum.

\section{3) Hidden Curriculum}

Merupakan segala kegiatan yang terjadi selama pembelajaran yang di luar rencana, seperti pendidikan disiplin yang diperoleh dari kebiasaan guru tepat waktu, ${ }^{12}$ baik dalam kedatangannya ke kelas atau dalam mengakhiri pelajaran, bahkan dalam hal konsistensinya menjalankan kesepakatan-kesepakatan antar dirinya dengan para murid. Selain dapat dilihat pada kebiasaan guru, Hidden Curriculum juga dapat diperhatikan pada kebiasaan yang

\footnotetext{
${ }^{9}$ Suparlan, Tanya Jawab Pengembangan Kurikulum dan Materi Pembelajaran, Jakarta, Bumi Aksara, 2011, h. 56-58.

${ }^{10}$ Ibid.

11 Ibid.

12 Ibid.
} 
terbangun pada masing-masing murid, ${ }^{13}$ seperti sebagian siswa saat istirahat belajar di sekolah berkumpul mendiskusikan pelajaran yang akan dipelajari pada jam pelajaran berikutnya atau menindaklajuti pelajaran yang telah disampaikan dalam suasana bincangbincang santai sambil menikmati snack dan sebagainya.

Munculnya konsep Hidden Curriculum ini sebenarnya sebagai efek dari kurikulum yang didefinisikan sebagai all the children experience. ${ }^{14}$ Boleh jadi dalam dokumen kurikulum, baik yang ideal atau yang riil, nilai-nilai multikultural seperti religius-humanis tidak tertera di dalamnya, atau hal itu hanya tertera pada dokumen kurikulum ideal tetapi dalam kurikulum faktual tidak tercantum atau tercantum hanya di sebagian matapelajaran dan sebagian bab saja, namun nilai-nilai religius-humanis tersebut sudah terlaksana secara rutin oleh setiap guru atau murid di sekolah tertentu secara tidak terprogram. Maka, yang demikian ini adalah kategori Hidden Curriculum. Seringkali, Hidden Curriculum memegang peranan penting dalam penciptaan sikap dan karakter murid. Yang perlu ditegaskan di sini adalah bahwa Hidden Curriculum itu bermata dua; negatif dan positif. ${ }^{15}$

\section{b. Perspektif Struktur dan Materi Pelajaran}

Klasifikasi kurikulum berdasarkan perspektif ini merupakan suatu pandangan terhadap kurikulum dengan pengertian sempit. Yaitu, kurikulum dipandang sebagai subject matter atau sebagai sekumpulan matapelajaran yang harus diterima oleh murid. Dikatakan demikian karena tiga ragam kurikulum yang akan dijelaskan ini berkaitan dengan pelajaran yang akan deberikan kepada murid itu secara temaik atau terpisah. Maka, kurikulum dari sudut pandang ini dapat diklasifikasi sebagai berikut: ${ }^{16}$

1) Sparated Curriculum

Sparated Curriculum dipahami sebagai struktur isi yang terpisah-pisah ke dalam beberapa matapelajaran sekalipun masih satu rumpun, misalnya rumpun bahasa Arab di madrasah atau madrasah diniyah yang dipecah-pecah menjadi matapelajaran muhadatsah, qira'ah, nahwu, sharf, dan sebagainya.

2) Broad Fields Curriculum

Kurikulum ini merupakan struktur isi yang menyatukan pelajaran-pelajaran yang memiliki keterkaitan erat, bukan keterkaitan jauh, menjadi satu matapelajaran, misalnya pada contoh pelajaran muhadatsah, qira'ah, nahwu, sharf menjadi matapelajaran Bahasa Arab. Contoh lain adalah Kimia, Fisika, dan Biologi, menjadi matapelajaran IPA, dan sebagainya.

${ }^{13}$ Abdullah Idi, Pengembangan Kurikulum; Teori dan Praktik, Jogjakarta, Ar-Ruzz Media, 2007, h. 51.

14 Ibid. h. 46.

15 Ibid. h. 51.

${ }^{16}$ Ibid. h. 141-147. 
3) Corelated Curriculum

Corelated Curriculum mengandung makna bahwa sejumlah matapelajaran dihubungkan antara yang satu dengan yang lain pada bab-bab atau Kompetensi Dasar tertentu yang bersinggungan antara satu matapelajaran dengan matapelajaran yang lain, misalnya di madrasah atau madrasah diniyah yang dicontohkan di atas terdapat matapelajaran Nahwu, Sharf, dan Qira'ah, maka dengan menggunakan Correlated Curriculum ini dapat dilakukan dengan cara melaksanakan pembelajaran Qira'ah yang sekaligus memerhatikan dan membahas kompetensi-kompetensi dasar yang ada di dalam matapelajaran Nahwu dan Sharf.

Contoh lain dari pelaksanaan Correlated Curriculum yaitu di madrasah ada matapelajaran Alqur'an Hadits, Fiqh, dan Aqidah Akhlaq. Tiga matapelajaran ini dapat disatukan dalam satu kegiatan pembelajaran untuk mencapai kompetensi dasar tertentu, misalnya pada pembahasan shalat (matapelajaran Fiqh) membahas fatihah sebagai salah satu rukunnya dan membaca surat pendek atau ayat pendek yang bermuatan ketauhidan atau akhlak (matapelajaran Aqidah Akhlaq). Saat guru dan murid mendiskusikan bacaan fatihah, surat pendek, atau ayat pendek, mereka sekaligus membahas hukum bacaan yang dibahas dalam ilmu tajwid (Alqur'an Hadits). Memang, desain kurikulum ini sangat berat dilakukan dan tidak banyak yang mampu melakukan. ${ }^{17}$

4) Integrated Curriculum

Kurikulum ini dipahami sebagai dokumen tentang organisasi isi (materi/konten) yang diatur secara tematik dan beberapa matapelajaran yang berhubungan dengan tematema yang telah dibuat digunakan untuk membahas tema-tema tersebut. Di Indonesia, Kurikulum Terintegrasi ini diterapkan di jenjang SD dan MI dari kelas I sampai kelas VI. Penerapan kurikulum ini di tingkat SD erat kaitannya dengan status guru yang ada di jenjang sekolah tersebut, yaitu sebagai guru kelas yang dituntut mampu menguasai berbagai macam matapelajaran. Dengan asumsi, mereka telah menguasainya, lalu pemerintah memberlakukan pembelajaran tematik yang tidak lagi matapelajaran yang disampaikan melainkan tema-tema yang diberikan kepada murid dengan berbagai sudut pandang matapelajaran terkait untuk membahas dan mempelajari tema-tema tersebut.

Dalam pembuatan tema, hendaknya guru memerhatikan kondisi peserta didik, lingkungan sekitar, dan kompetensi guru, alokasi waktu yang tersedia. Perhatian guru pada saat melaksanakan pembelajaran tidak lagi fokus pada satu matapelajaran, tetapi menyeluruh kepada semua matapelajaran terkait untuk memahami tema yang dibahas. Sebagai contoh

17 Realisasi Correlated Curruculum ini mengesankan adanya proses menuju pembelajaran tematik, atau bahkan sudah tegolong pembelajaran tematik. Dalam pembelajaran 
pada matapelajaran PAI yang dapat diintegrasikan dengan beberapa matapelajaran adalah hal-hal yang berkaitan dengan akhlak mulia dan sopan santun baik di rumah, sekolah, dan masyarakat, serta nilai-nilai pendidikan karakter bangsa. Sedangkan materi-materi PAI bidang aqidah dan amal ibadah tetap disajikan mandiri oleh Guru PAI. Dalam hal ini, pendidikan multikultural menemukan momentum untuk diterapkan dengan cara nilai-nilai multikultural dapat dijadikan tema dan disaritemukan dengan salah satu kompetensi dasar pada beberapa matapelajaran lain, misalnya tema tentang toleransi, humanis, moderat, dan sebagainya.

Ada beberapa langkah yang harus dilakukan dalam penerapan pembelajaran tematik, yaitu:

a) Penentuan Tema, yaitu guru menelaah semua matapelajaran untuk mencaritemukan KD-KD yang bersinggungan antara satu matapelajaran dengan matapelajaran yang lain dan selanjutnya guru menentukan tema-tema yang akan dibahas selama 1 tahun berdasarkan kesamaan-kesamaan pada beberapa matapelajaran tersebut.

b) Analisis Kompetensi, yaitu guru mempelajari Standar Kompetensi Lulusan (SKL), Kompetensi Inti (KI), Kompetensi Dasar (KD) yang ada pada masing-masing matapelajaran.

c) Analisis Tema dengan Kompetensi, yaitu guru membandingkan tema-tema yang telah dibuat selama 1 tahun dengan SKL, KI, dan KD yang telah dipelajari, dan selanjutnya guru membuat hubungan antara tema dengan kompetensi tersebut.

d) Penyusunan Indikator, yaitu guru membuat Indikator dari masing-masing tema yang telah dibuat sebelumnya berdasarkan $\mathrm{KD}$ yang juga telah dibuat pada tahap sebelumnya.

e) Penyusunan Silabus Tematik.

f) Penyusunan Rencana Pelaksanaan Pembelajaran (RPP) Tematik sebagai pijakan dan panduan pelaksanaan pembelajaran. ${ }^{18}$

Peluang guru memasukkan nilai-nilai multikulturalisme dalam pembelajaran sangat luas pada Pembelajaran Tematik Terpadu (PTP) ini. Pada KI-1 dan KI-2 sudah jelas tertuang nilai-nilai multikultural yaitu siswa diharapkan mampu mengamalkan ajaran agama yang dianutnya, tentu hal ini dijalankan penuh toleran. Begitu pula pada KI-2 yang menekankan pada penanaman sikap dan perilaku sosial yang mencerminkan budaya bangsa yang plural. Dari KI yang telah ditetapkan secara nasional, lalu KD yang telah ditentukan pada masing-masing matapelajaran dimodifikasi oleh guru untuk dibuat KD Tematik yang

18 Dirman dan Cicih Juarsih, Pengembangan Kurikulum dalam Rangka Implementasi Standar Proses Pendidikan Siswa, Jakarta, Rineka Cipta, 2014, h. 112 dan 114. 
selanjutnya dibuatkan Indikator Tematik pula. Pada tahap tematisasi KD dan Indikator ini, guru berpeluang besar mengintegrasikan nilai-nilai multikulturalisme dalam KD dan Indikator baru.

Dari empat klasifikasi kurikulum berdasarkan subject matter versi Dr. Abdullah Idi, M.Ed. di atas masih belum begitu tampak jelas hal yang membedakan antara Corrrelated Curriculum dan Integrated Curriculum. Perbedaan yang penulis terima berdasarkan paparannya adalah terletak pada pola kerja implementasi kurikulum tersebut, yaitu Corrrelated Curriculum berupa penyatuan beberapa matapelajaran menjadi satu tema namun tidak sampai dirumuskan pada integrasi KD, Indokator, pembuatan silabus, dan RPP, sedangkan dalam Integrated Curriculum hal itu semua dilakukan secara rinci. Jika benar asumsi ini, maka sebenarnya antara Corrrelated Curriculum dan Integrated Curriculum tidak ada perbedaan prinsip, sehingga klasifikasi kurikulum dari sudut pandang subject matter ini hanya ada tiga: Sparated Curriculum, Broad Fields Curriculum, dan Integrated Curriculum/Correlated Curriculum.

\section{c. Perspektif Ruang Lingkup Penggunaan}

Klasifikasi kurikulum berdasarkan perspektif ini sangat boleh jadi berbeda antara satu negara dengan negara lain. Dalam buku Suparlan, M.Ed. disebutkan bahwa klasifikasi kurikulum berdasarkan perspektif ini terbagi menjadi tiga, yaitu: kurikulum nasional, kurikulum negara bagian, dan kurikulum sekolah. ${ }^{19}$ Negara yang tidak menganut sistem pembagian wilayah seperti di atas tidak memiliki kurikulum negara bagian, yang ada hanyalah kurikulum nasional dan kurikulum institusional atau sekolah. Maka dari itu, Dr. Abdullah Idi, M.Ed. menguraikan klasifikasi kurikulum menjadi Co-Curriculum dan Local Curriculum.

1) Co-Curriculum

Co-Curriculum atau Core Curriculum dalam bahasa Indonesia disebut Kurikulum Inti dan dikenal pula dengan Kurikulum Nasional. Disebut Kurikulum Inti dan Kurikulum Nasional karena kurikulum ini dinilai sebagai matapelajaran dan proses pokok/utama yang harus dilakukan sekolah-sekolah secara nasional dari tingkat pusat hingga daerah-daerah. Berikut ini adalah konten Co-Curriculum di jenjang Sekolah Dasar/Madrasah Ibtidaiyah:

${ }^{19}$ Suparlan, Tanya Jawab Pengembangan Kurikulum dan Materi Pembelajaran, Jakarta, Bumi Aksara, 2011, h. 58. 
Volume 6 Nomor 1 Desember 2020

Tabel $1^{20}$

\begin{tabular}{|c|c|c|c|c|c|c|c|}
\hline \multirow{2}{*}{\multicolumn{2}{|c|}{$\begin{array}{ll}\text { NO } & \text { MATAPELAJARAN } \\
\text { Kelompok A } & \\
\end{array}$}} & \multicolumn{6}{|c|}{ KELAS } \\
\hline & & I & II & $\overline{\mathrm{III}}$ & IV & $\mathrm{V}$ & $\overline{\mathrm{VI}}$ \\
\hline 1 & Pendidikan Agama Islam dan Budi Pekerti & $\sqrt{ }$ & $\sqrt{ }$ & $\sqrt{ }$ & $\sqrt{ }$ & $\sqrt{ }$ & $\sqrt{ }$ \\
\hline 2 & Pendidikan Pancasila dan Kewarganegaraan & $\sqrt{ }$ & $\sqrt{ }$ & $\sqrt{ }$ & $\sqrt{ }$ & $\sqrt{ }$ & $\sqrt{ }$ \\
\hline 3 & Bahasa Indonesia & $\sqrt{ }$ & $\sqrt{ }$ & $\sqrt{ }$ & $\sqrt{ }$ & $\sqrt{ }$ & $\sqrt{ }$ \\
\hline 4 & Matematika & $\sqrt{ }$ & $\sqrt{ }$ & $\sqrt{ }$ & $\sqrt{ }$ & $\sqrt{ }$ & $\sqrt{ }$ \\
\hline 5 & Ilmu Pengetahuan Alam & - & - & - & $\sqrt{ }$ & $\sqrt{ }$ & $\sqrt{ }$ \\
\hline 6 & Ilmu Pengetahuan Sosial & - & - & - & $\sqrt{ }$ & $\sqrt{ }$ & $\sqrt{ }$ \\
\hline \multicolumn{2}{|c|}{ Kelompok B } & $\sqrt{ }$ & $\sqrt{ }$ & $\sqrt{ }$ & $\sqrt{ }$ & $\sqrt{ }$ & $\sqrt{ }$ \\
\hline 1 & Seni Budaya dan Prakarya & $\sqrt{ }$ & $\sqrt{ }$ & $\sqrt{ }$ & $\sqrt{ }$ & $\sqrt{ }$ & $\sqrt{ }$ \\
\hline 2 & Pendidikan Jasmani, Olahraga, dan Kesehatan & $\sqrt{ }$ & $\sqrt{ }$ & $\sqrt{ }$ & $\sqrt{ }$ & $\sqrt{ }$ & $\sqrt{ }$ \\
\hline
\end{tabular}

Sedangkan struktur Kurikulum Inti di jenjang Sekolah Menengah

Pertama/Madrasah Tsanawiyah adalah:

Tabel $2^{21}$

\begin{tabular}{llrrr}
\hline $\mathbf{N}$ & \multicolumn{1}{c}{ MATAPELAJARAN } & \multicolumn{2}{c}{ KELAS } \\
$\mathbf{O}$ & VII & VIII & IX \\
\hline Kelompok A & $\sqrt{ }$ & $\sqrt{ }$ & $\sqrt{ }$ \\
\hline 1 & Pendidikan Agama Islam dan Budi Pekerti & $\sqrt{ }$ & $\sqrt{ }$ & $\sqrt{ }$ \\
\hline 2 & Pendidikan Pancasila dan Kewarganegaraan & $\sqrt{ }$ & $\sqrt{ }$ \\
\hline 3 & Bahasa Indonesia & $\sqrt{ }$ & $\sqrt{ }$ \\
\hline 4 & Matematika & $\sqrt{ }$ & $\sqrt{ }$ \\
\hline 5 & Ilmu Pengetahuan Alam & $\sqrt{ }$ & $\sqrt{ }$ \\
\hline 6 & Ilmu Pengetahuan Sosial & & & \\
\hline 7 & Bahasa Inggris & $\sqrt{ }$ & $\sqrt{ }$ \\
\hline Kelompok B & $\sqrt{ }$ & $\sqrt{ }$ & $\sqrt{ }$ \\
\hline 1 & Seni Budaya & $\sqrt{ }$ & $\sqrt{ }$ \\
\hline 2 & Pendidikan Jasmani, Olahraga, dan Kesehatan & $\sqrt{ }$ & $\sqrt{ }$ \\
\hline 3 & Prakarya & Sementara strktur Co-Carning
\end{tabular}

Sementara struktur Co-Curriculum jenjang Sekolah Menengah Atas, Madrasah Aliyah,

dan Sekolah Menengah Kejuruan, yang selain matapelajaran peminatan adalah:

Tabel $3^{22}$

\begin{tabular}{|c|c|c|c|c|}
\hline \multirow{2}{*}{ NO } & \multirow{2}{*}{ MATAPELAJARAN } & \multicolumn{3}{|c|}{ KELAS } \\
\hline & & $\mathbf{X}$ & $\mathbf{X I}$ & XII \\
\hline \multicolumn{5}{|c|}{ Kelompok A } \\
\hline 1 & Pendidikan Agama Islam dan Budi Pekerti & $\sqrt{ }$ & $\sqrt{ }$ & $\sqrt{ }$ \\
\hline 2 & Pendidikan Pancasila dan Kewarganegaraan & $\sqrt{ }$ & $\sqrt{ }$ & $\sqrt{ }$ \\
\hline 3 & Bahasa Indonesia & $\sqrt{ }$ & $\sqrt{ }$ & $\sqrt{ }$ \\
\hline 4 & Matematika & $\sqrt{ }$ & $\sqrt{ }$ & $\sqrt{ }$ \\
\hline 5 & Sejarah Indonesia & $\sqrt{ }$ & $\sqrt{ }$ & $\sqrt{ }$ \\
\hline 6 & Bahasa Inggris & $\sqrt{ }$ & $\sqrt{ }$ & $\sqrt{ }$ \\
\hline \multicolumn{5}{|c|}{ Kelompok B } \\
\hline 1 & Seni Budaya & $\sqrt{ }$ & $\sqrt{ }$ & $\sqrt{ }$ \\
\hline 2 & Pendidikan Jasmani, Olahraga, dan Kesehatan & $\sqrt{ }$ & $\sqrt{ }$ & $\sqrt{ }$ \\
\hline 3 & Prakarya dan Kewirausahaan & $\sqrt{ }$ & $\sqrt{ }$ & $\sqrt{ }$ \\
\hline
\end{tabular}

20 Lihat: Salinan Lampiran Peraturan Menteri Pendidikan dan Kebudayaan Nomor 67 Tahun 2013 tentang Kerangka Dasar dan Struktur Kurikulum Sekolah Dasar/Madrasah Ibtidaiyah, h. 9.

21 Lihat: Salinan Lampiran Peraturan Menteri Pendidikan dan Kebudayaan Nomor 68 Tahun 2013 tentang Kerangka Dasar dan Struktur Kurikulum Sekolah Menengah Pertama/Madrasah Tsanawiyah, h. 7.

22 Lihat: Salinan Lampiran Peraturan Menteri Pendidikan dan Kebudayaan Nomor 69 Tahun 2013 tentang Kerangka Dasar dan Struktur Kurikulum Sekolah Menengah Atas/Madrasah Aliyah, h. 9. 
Matapelajaran-matapelajaran pada tabel 3 di atas, ditambah beberapa matapelajaran peminatan di masing-masing jenis sekolah, baik jenis SMA, MA, atau SMK. Matapelajaranmatapelajaran peminatan dimaksud adalah:

Tabel $4^{23}$

\begin{tabular}{|c|c|c|c|c|}
\hline \multirow{2}{*}{ NO } & \multirow{2}{*}{ MATAPELAJARAN } & \multicolumn{3}{|c|}{ KELAS } \\
\hline & & $\mathbf{X}$ & $\mathrm{XI}$ & $\mathrm{XII}$ \\
\hline \multicolumn{5}{|c|}{ Peminatan Matematika dan Ilmu Alam } \\
\hline 1 & Matematika & $\sqrt{ }$ & $\sqrt{ }$ & $\sqrt{ }$ \\
\hline 2 & Biologi & $\sqrt{ }$ & $\sqrt{ }$ & $\sqrt{ }$ \\
\hline 3 & Fisika & $\sqrt{ }$ & $\sqrt{ }$ & $\sqrt{ }$ \\
\hline 4 & Kimia & $\sqrt{ }$ & $\sqrt{ }$ & $\sqrt{ }$ \\
\hline \multicolumn{5}{|c|}{ Peminatan Ilmu-ilmu Sosial } \\
\hline 1 & Geografi & $\sqrt{ }$ & $\sqrt{ }$ & $\sqrt{ }$ \\
\hline 2 & Sejarah & $\sqrt{ }$ & $\sqrt{ }$ & $\sqrt{ }$ \\
\hline 3 & Sosiologi & $\sqrt{ }$ & $\sqrt{ }$ & $\sqrt{ }$ \\
\hline 4 & Ekonomi & $\sqrt{ }$ & $\sqrt{ }$ & $\sqrt{ }$ \\
\hline \multicolumn{5}{|c|}{ Peminatan Ilmu Bahasa dan Budaya } \\
\hline 1 & Bahasa dan Sastra Indonesia & $\sqrt{ }$ & $\sqrt{ }$ & $\sqrt{ }$ \\
\hline 2 & Bahasa dan Sastra Inggris & $\sqrt{ }$ & $\sqrt{ }$ & $\sqrt{ }$ \\
\hline 3 & Bahasa Asing Lain (Arab, Jepang, Mandarin, Prancis) & $\sqrt{ }$ & $\sqrt{ }$ & $\sqrt{ }$ \\
\hline 4 & Antropologi & $\sqrt{ }$ & $\sqrt{ }$ & $\sqrt{ }$ \\
\hline
\end{tabular}

\section{2) Local Curriculum}

Local Curriculum disebut juga dengan istilah Kurikulum Muatan Lokal. Kurikulum ini dipahami sebagai kurikulum wajib bagi setiap murid yang berisi materi dan cara penyampaian yang dikaitkan -baik secara langsung atau tidak - dengan lingkungan alam, lingkungan sosial, serta lingkungan budaya, dan kebutuhan daerah sekitar sekolah. ${ }^{24}$ Kurikulum Muatan Lokal yang diapresiasi Kurikulum Nasional sebesar 20\%. Hal ini sesuai dengan salah satu fungsi pendidikan yaitu sebagai pewaris atau pelestari budaya suatu generasi ke generasi berikutnya. Dalam konteks pengembangan Kurikulum Muatan Lokal ini, sekolah yang memiliki visi multikulturalisme dapat memasukkan nilai-nilai multikulturalisme dalam Kurikulum Muatan Lokal, terutama sekolah-sekolah yang berlingkungan masyarakat multikultur.

\section{Asas-asas Kurikulum Pendidikan Multikultural}

Dijumpai empat asas desain kurikulum menurut Kementerian Agama Republik Indonesia, yaitu: ${ }^{25}$

23 Lihat: Salinan Lampiran Peraturan Menteri Pendidikan dan Kebudayaan Nomor 69 Tahun 2013 tentang Kerangka Dasar dan Struktur Kurikulum Sekolah Menengah Atas/Madrasah Aliyah, h. 12.

24 Abdullah Idi, Ibid., h. 260.

${ }^{25}$ Departemen Agama R.I, Ibid. h. 61-73. 
a. Asas Psikologi Anak

Kajian psikologi atas peserta didik merupakan hal yang mesti dilakukan. Hal ini disebabkan oleh, selain peserta didik mengalami perkembangan fisik dan kejiwaan, mereka juga memiliki kondisi psikis yang bervariasi antar yang satu dengan lainnya. Menyikapi realita seperti ini, para pendidik dalam melaksanakan pendidikan dan pembelajaran harus memerhatikan semua hal itu, supaya tujuan pendidikan dan pembelajaran tercapai sesuai yang diharapkan. Perubahan arah pelaksanaan kurikulum pada tahap pembelajaran, dari pendekatan teacher centered ke student centered dengan model pembelajaran kooperatif dengan segala bentuk tipenya, merupakan implementasi dari penyusunan kurikulum berdasarkan asas psikologi ${ }^{26}$.

Asas psikologi dalam kaitannya dengan kurikulum ini berkaitan langsung dengan kurikulum pada tataran implementasinya dalam pembelajaran (instruction). Dalam buku yang ditulis Abdullah Idi, misalnya, memberikan kesan demikian, karena di dalamnya dia mengulas teori-teori belajar seperti teori behaviorisme, teori Gestalt, teori psikologi daya, teori pengembangan kognitif, dan teori kepribadian. ${ }^{27}$ Pendidikan seharusnya mampu mengakomudir seluruh varian kondisi psikologi anak bangsa. Tidak dibenarkan pendidikan hanya mengayomi mereka yang berkemampuan bagus, berjiwa stabil, dan sebagainya, sedangkan anak bangsa yang aspek kognitifnya lemah, berjiwa abnormal, dan semacamnya tidak diterima. Pada aspek ini, pendidikan inklusi sebagai salah satu nilai kesertaraan yang terdapat dalam lingkup multikulturalisme memegang peranan penting untuk diterapkan.

b. Asas Sosiologi Bangsa

Luas wilayah negara Indonesia yang terpencar di berbagai belahan daratan dan kepulauan memiliki karakteristik yang beraneka ragam. Di antara mereka ada yang tinggal di pedesaan dan perkotaan, daratan dan kepulauan, daerah urban dan rural. Selain itu, mereka juga berbagai ragam suku, ras, bahasa, agama dan semacamnya. Realita ini merupakan kekayaan dari satu sisi dan sumber konflik di sisi yang lain. Seluruh ragam karakteristik tersebut harus diakomudir oleh kurikulum suatu pendidikan. Untuk mengakomudir ini, menurut Dakir, Kurikulum Muatan Lokal harus didasarkan pada keadaan lingkungan setempat, ${ }^{28}$ sehingga seluruh ragam perbedaan di atas terwadahi dalam pendidikan yang bercorak inklusif multikulturalis.

c. Asas Perkembangan IPTEK dunia

Perkembangan IPTEK (Ilmu Pengetahuan Teknologi dan Seni) di Indonesia secara jujur diakui masih ketinggalan kalau dibandingkan dengan negara-negara maju lainnya. Oleh karena itu bahan-bahan

\footnotetext{
26 Achmad Yusuf. "PENGEMBANGAN KURIKULUM PAI BERBASIS MULTIKULTURAL (Perspektif Psikologi Pembelajaran)”. AL MURABBI 4, no. 2 (May 25, 2019): 251-274..

${ }^{27}$ Abdullah Idi, Ibid., h. 79 dan seterusnya.

${ }^{28}$ Departemen Agama RI, Ibid., h. 59.
} 
yang berupa IPTEK yang dicantumkan dalam kurikulum di Indonesia masih selalu dikejar. ${ }^{29}$ Usaha mengejar ketertinggalan ini harus dirumuskan dalam kurikulum pendidikan sejak di tingkat nasional hingga tingkat intruksional. Bahkan, pengitegrasian pembelajaran dengan pemanfaatan media teknologi dalam pembelajaran sangat dipengaruhi oleh perkembangan IPTEK yang mengalami kemajuan pesat dan sulit dibendung. Apalagi di era teknologi informasi belakangan ini.

d. Asas Pancasila sebagai Filsafat Bangsa

Nasution, sebagaimana dikutip Abdullah Idi, menyarankan agar para pengembang kurikulum (curriculum developers) di dalam mengembangkan kurikulum harus mempertimbangkan falsafah negara, falsafah institusi, dan falsafah yang dianut oleh para tenaga pendidik dan kependidikan. ${ }^{30}$ Beberapa falsafah tersebut harus disingkronisasi secara simultan antar masing-masing sehingga kurikulum yang dibangun merupakan cermin dari pendidikan nasional yang tak mengabaikan local wisdom sebagai ciri khas lembaga. Pandangan hidup bangsa Indonesia adalah Pancasila. Dengan sendirinya, segala kegiatan yang dilakukan baik oleh berbagai lembaga atau perorangan, harapannya tidak boleh bertentangan dengan asas pancasila, termasuk dalam kegiatan penyusunan kurikulum. ${ }^{31}$

\section{Prinsip Penyusunan Kurikulum dalam Pendidikan Multikultural}

Nana Syaodih menulis dua prinsip dalam desain kurikulum, yaitu prinsip umum dan khusus. Ada empat prinsip umum dalam penyusunan kurikulum pendidikan, yaitu prinsip relevansi, fleksibelitas, kontinuitas, efisien, dan efektif. ${ }^{32}$

a. Prinsip Relevansi, yaitu kurikulum yang dirancang tidak hanya harus relevan dengan seluruh komponen kurikulum yang terdiri dari tujuan, isi, proses, dan evaluasi, tetapi kurikulum juga harus relevan dengan tuntutan perkembangan di luar sekolah dan kebutuhan dunia. Di saat, lembaga pendidikan hendak mengusung multikultural dan mengintegrasikannya ke dalam praktik pendidikan, maka harus tertuang nilai-nilai multikultural pada visi atau tujuan, isi, proses, dan evaluasi sebagai cerminan dari lingkungan sekolah yang multikultur.

b. Prinsip Fleksibelitas, yaitu Kurikulum mempersiapkan anak untuk kehidupan sekarang dan akan datang, di sini dan di tempat lain, bagi anak yang memiliki latar belakang kemampuan berbeda. Prinsip fleksibelitas ini cukup relevan dengan multikulturalisme dalam dunia pendidikan karena prinsip ini menuntut adanya sikap inklusif dalam praktik pendidikan.

c. Prinsip Kontiuitas, yaitu pengalaman-pengalaman belajar yang disediakan kurikulum hendaknya berkesinambungan antara satu tingkat kelas, dengan kelas lainnya, antara satu jenjang pandidikan

\footnotetext{
${ }^{29}$ Ibid.

30 Abdullah Idi, Ibid., h. 69.

31 Departemen Agama RI, Ibid., h. 73.

32 Nana Syaodih Sukmadinata, Pengembangan Kurikulum Teori dan Praktek, Bandung, PT. Remaja Rosdakarya, 2004, h.
} 150-151. 
Volume 6 Nomor 1 Desember 2020

dengan jenjang pendidikan lainnya, juga antara jenjang pendidikan dengan pekerjaan. Yang sering menjadi kendala adalah saat satu lembaga sudah mengintegrasikan nilai-nilai multikulturalisme namun jenjang di bawah atau di atasnya tidak seirama dengan sekolah multikultural. Solusinya ada adanya konsorsium pengembangan keilmuan yang berwawasan multikultural yang beranggotakan para pemengang kebijakan di sekolah-sekolah dalam satu kabupaten atau provinsi.

d. Prinsip Efisiensi, yaitu kerangka kurikulum harus mudah dilaksanakan, menggunakan alat-alat sederhana dan biaya juga murah.

e. Prinsip Efektif, yaitu meskipun kurikulum tersebut harus murah, sederhana dan murah tapi keberhasilannya tetap harus diperhatikan. Keberhasilan kurikulum ini baik secara kuantitas maupun kualitas. Supaya nilai-nilai multikulturalisme mudah terwujud (efektif dan efisien), wujud pendidikan multikultural tidak perlu berwujud matapelajaran namun cukup mengintegrasikan nilai-nilai multikulturalisme ke dalam isi, proses, dan evaluasi pembelajaran.

Sedangkan prinsip khusus desain kurikulum pendidikan adalah prinsip berkenaan dengan tujuan pendidikan di suatu sekolah tertentu, prinsip berkenaan dengan pemilihan konten yang sesuai dengan tujuan, prinsip berkenaan dengan pemilihan proses pembelajaran, prinsip berkenaan dengan pemilihan media dan alat pembelajaran, dan prinsip berkenaan dengan pemilihan penilaian. ${ }^{33}$

\section{KESIMPULAN}

Berdasarkan kajian di atas bahwa klasifikasi Kurikulum Berbasis Multikultural Setidaknya ada tiga sudut pandang untuk membagi kurikulum, yaitu kurikulum dipandang dari segi konsep dan pelaksanaannya, dari segi struktur dan materi pelajarannya, dan dari segi proses penyusunannya.

Pertama: Perspektif Konsep dan Pelaksanaan diklasifikasikan ke dalam tiga kelompok, (a) Kurikulum Ideal: yaitu dokumen-dokumen ideal tentang pelaksanaan pembelajaran yang dicita-citakan yang seharusnya dicapai. (2) Kurikulum Faktual yaitu dokumen-dokumen dari seluruh kegiatan pembelajaran yang riil diterapkan oleh guru-murid di bawah supervisi kepala sekolah. (3) Hidden Curriculum yaitu segala kegiatan yang terjadi selama pembelajaran yang di luar rencana, seperti pendidikan disiplin yang diperoleh dari kebiasaan guru tepat waktu, ${ }^{34}$ baik dalam kedatangannya ke kelas atau dalam mengakhiri pelajaran, bahkan dalam hal konsistensinya menjalankan kesepakatan-kesepakatan antar dirinya dengan para murid.

Kedua: Perspektif Struktur dan Materi Pelajaran Klasifikasi kurikulum berdasarkan perspektif terdiri dari (1) Sparated Curriculum. Yaitu sebagai struktur isi yang terpisah-pisah ke dalam beberapa matapelajaran sekalipun masih satu rumpun.(2) Broad Fields Curriculum yaitu merupakan struktur isi yang menyatukan pelajaran-pelajaran yang memiliki keterkaitan erat, bukan keterkaitan jauh, menjadi satu

33 Ibid., 152-154.

${ }^{34}$ Ibid. 
mata pelajaran. (3) Corelated Curriculum yaitu bahwa sejumlah matapelajaran dihubungkan antara yang satu dengan yang lain pada bab-bab atau Kompetensi Dasar tertentu yang bersinggungan antara satu matapelajaran dengan matapelajaran yang lain. (4) Integrated Curriculum yaitu dokumen tentang organisasi isi (materi/konten) yang diatur secara tematik dan beberapa matapelajaran yang berhubungan dengan tema-tema yang telah dibuat digunakan untuk membahas tema-tema tersebut.

Ketiga: Perspektif Ruang Lingkup Penggunaan Klasifikasi kurikulum berdasarkan perspektif terbagi menjadi tiga, yaitu: kurikulum nasional, kurikulum negara bagian, dan kurikulum sekolah sedangkan menurut Abdullah Idi menguraikan klasifikasi kurikulum menjadi Co-Curriculum dan Local Curriculum.

Asas-asas dalam mendesain kurikulum berbasis multicultural yaitu (1) Asas Psikologi Anak, (2) Asas Sosiologi Bangsa, (3) Asas Perkembangan IPTEK dunia, dan (4) Asas Pancasila sebagai Filsafat Bangsa. Sedangkan Prinsip Penyusunan Kurikulum dalam Pendidikan Multikultural meliputi: (1) prinsip relevansi, (2) fleksibelitas, (3) kontinuitas, (4) efisien, dan (5) efektif.

\section{DAFTAR PUSTAKA}

Achmad Yusuf. "PENGEMBANGAN KURIKULUM PAI BERBASIS MULTIKULTURAL (Perspektif Psikologi Pembelajaran)". AL MURABBI 4, no. 2 (May 25, 2019): 251-274. Accessed November, 2020. https://jurnal.yudharta.ac.id/v2/index.php/pai/article/view/1453.

Abdullah Idi, Pengembangan Kurikulum; Teori dan Praktik, Jogjakarta, Ar-Ruzz Media, 2007. Abdullah Aly, Pendidikan Islam Multikultural di Pesantren: Telaah terhadap Kurikulum Pondok Pesantren Modern Islam Assalam Surakarta, Yogyakarta, Pustaka Belajar, 2011.

Ali Mudlofir, Aplikasi Pengembangan Kurikulum Tingkat Satuan Pendidikan dan Bahan Ajar dalam Pendidikan Agama Islam, Jakarta, Rajagrafindo Persada, 2011.

Anis Farikhatin et.al., Mengelola Keragaman di Sekolah: Gagasan dan Pengalaman Guru, Yogyakarta, CRCS Sekolah Pascasarjana UGM, 2016.

Dakir, Perncanaan Dan Pengembangan Kurikulum, Jakarta, Rineka Cipta, 2004.

Dirman dan Cicih Juarsih, Pengembangan Kurikulum dalam Rangka Implementasi Standar Proses Pendidikan Siswa, Jakarta, Rineka Cipta, 2014.

Nana Syaodih Sukmadinata, Pengembangan Kurikulum Teori dan Praktek, Bandung, PT. Remaja Rosdakarya, 2004.

Nik Nurhayati, Pengembangan Kurikulum Pendidikan Agama Islam, Bandung, Alfabeta, 2011.

Peraturan Menteri Agama Nomor 912 Tahun 2013 tentang Kurikulum Madrasah 2013 Matapelajaran Pendidikan Agama Islam dan Bahasa Arab BAB I Nomor 2 Sub a Pengertian Kurikulum.

Salinan Lampiran Peraturan Menteri Pendidikan dan Kebudayaan Nomor 67 Tahun 2013 tentang Kerangka Dasar dan Struktur Kurikulum Sekolah Dasar/Madrasah Ibtidaiyah.

Salinan Lampiran Peraturan Menteri Pendidikan dan Kebudayaan Nomor 68 Tahun 2013 tentang Kerangka Dasar dan Struktur Kurikulum Sekolah Menengah Pertama/Madrasah Tsanawiyah.

Salinan Lampiran Peraturan Menteri Pendidikan dan Kebudayaan Nomor 69 Tahun 2013 tentang Kerangka Dasar dan Struktur Kurikulum Sekolah Menengah Atas/Madrasah Aliyah. 
AL MURABBI: Jurnal Pendidikan Agama Islam https://jurnal.yudharta.ac.id/v2/index.php/pai Volume 6 Nomor 1 Desember 2020

Suparlan, Tanya Jawab Pengembangan Kurikulum dan Materi Pembelajaran, Jakarta, Bumi Aksara, 2011.

Undang-undang Nomor 20 Tahun 2003 tentang Sistem Pendidikan Nasional BAB I, Pasal 1 Nomor (19). 